\title{
Need Analysis of Virtual Laboratories For Science Education In Jambi, Indonesia
}

\author{
Fahmi Rohim \\ Prodi Pendidikan Guru Madrasah Ibtidaiyah, STAI Ahsanta Jambi, Indonesia \\ Email: fahmi.rohim.fr@gmail.com
}

\begin{abstract}
The needs of technological advancement which is infused into education system are more and more inviting thorough researches since digital environment influences educational settings. In specific, virtual laboratories as the digital environment is now not used only in engineering and computer science fields but also in educational field in general. Digitalized teaching aids, web-based learning, elearning etc. are such possible prospective fields that need virtual labs in them. In regard to that, this study is initiated to conduct a need analysis of virtual labs for Jambi province context through library research. This study employs documentary analysis techniques to assimilate reliable information regarding virtual labs from the related literatures. Purposively, this study selects online journals that are correlated to virtual labs and analysed the variables, methods, and results of study. This study finds that studies done yield few shortcomings of virtual labs usages to only the lost opportunity of students to involve their senses during the use of virtual labs. However, in general virtual labs usages contribute benefits to science education such as: a) Virtual labs assist students to link between theoretical and scientific concepts to practical laboratory techniques and skills; b) Virtual labs provide simulations that make students more engaged in learning scientific phenomena; c) Although some important opportunities of learning experiences are not provided by virtual labs such as sensory involvement in learning, most virtual labs are developed to fulfil the characteristics of teaching aids; d) Virtual labs abbreviate the preparation steps of practicum activities, hence they make class-time used effectively; and e) Virtual labs allow students to repeat experiment for multiple times. In addition, virtual labs usages also bring prospects to some important aspects of educational field namely financial resources, academic advancement, technological computer simulation improvement, and cultural aspects. This study suggests the Jambi Education Board to recommend virtual labs usages at schools to equip science education as supplemental and supporting teaching aids.
\end{abstract}

Keywords: Need analysis, virtual labs, academic advancement

\section{INTRODUCTION}

Education in the contemporary era have seen schools embracing technology to enhance the teaching and learning process in a more engaging and interactive way for new age students. More than ever before, computer technology development provides more sophistication to support teaching and learning in educational systems. Basically, most computers are built and designed with advanced learning tools and learning apps. Computer in the past used to have a limited scope and operational purposes within the school system, for instance, the use was limited to administrative and low-end calculation operations. In the modern era, the advancement of computers for learning purpose also support students to learn in more sophisticated and 
engaging ways, such as through online based learning, virtual classroom, E-library system, flip learning and so on.

Tech developers are committed to and working earnestly in their apt to lead technological innovations with a focus on developing devices and or software for educational supports. This corroborates the wide advocacy for the adoption technological advancement for the development of education. Due to this, there is a paradigm shift in the schools system in the 21st Century as there is a major change in frameworks, models, tools which are employed, etc. take for instance the shift from Rote learning to Blended Learning, with various approaches. The shift to blended learning methods have led to a more interesting and interactive classroom environment which encourages a desired learning experience and output. Learning is no more limited to cramming definitions, occasionally patronising physical labs for science based subjects or learning complicated structures or formula with image imprints on the text books, learning now requires real life experiences, therefore virtual labs as an educational tool offers a conducive environment for learning which could be visited at students' wish and further give room to learning at their own pace (Johnson, Adams Becker, Estrada, And Freeman, 2015).

Essentially, this research paper emphasizes on science education as the subject of the study. It is considered that Science education borders on providing direct experience to develop the competence of the student. Furthermore, it adds great possibilities to take draw from technological development. Physics which involves analysing, computing, calculating, and manipulating either facts or concepts requires a great deal of direct experience through practical activities. The effective implementation of practicum in physics class will in turn help students to gain a broader experience of the natural surroundings through the application of formula, concepts, and theories during the real implementation in which the students are involved (Karadeniz, 2013).

Giving a general view, science is next to everyday life as it entails the students observing and experiencing the physical surroundings. Therefore, the science subject is selected to allow for emphasis on the implementation of practical activities to provide students with a deep understanding on the rules, laws, and principles that govern nature. However, practical activities in schools still have their constraints; activities in the chemistry lab also have its challenges which may include expensive laboratory equipment, limited laboratory facilities, as well as practical difficulties in abstract science concepts. In addition, minor school laboratory accidents are among such as cuts, heat burns/scalds, exposure of the skin to chemicals, chemical spillage, eye accidents, fire, inhalation of gasses, and organism stings ("Common Labs Accident," n.d. http://cd1.edb.hkedcity.net/cd/science/laboratory/ cla/cla.html retrieved on 7th November 2016). The abstract state of studying physics is also a difficulty especially when showing physical processes directly through the laboratory. This issue leads to a very low mastery level of the concepts of science for the students. 
It is believed that if practical exercises are carried out, it will increase the motivation, understanding, as well as social and personal skills of students.

In response to that condition, technology appears to offer a lasting solution by providing virtual laboratories in form of virtual computer environments that are built as close as possible to the physical laboratories environment. Virtual laboratories are developed to meet the needs of both conventional face to face classroom especially in science laboratories and distance learning. Recently, virtual laboratories have been adopted by higher institutions. They are incorporated not only for online courses but also as for alternatives to physical laboratories. Initially, as Jagannathan (2016) maintains that virtual labs were used initially in the fields of engineering and computer science, but as time went on, several other disciplines such as e-learning system has adopted them.

Conceptually, many literatures propose definitions for virtual labs. Amorim, Tapparo, Maranghello, Silva, And Pereira (2014) portray an overview of virtual laboratories by defining virtual laboratories as simulation-based interactive labs used to interactively design and conduct controlled experiments. The National Research Council in National Academy Press 2006 state that both physical and virtual laboratories can achieve similar objectives, such as exploring the nature of science, developing team work abilities, cultivating and sustaining interests in science, promoting conceptual understanding, and developing inquiry skills, with specific affordances (De Jong, Linn, And Zacharia, 2013).

However, their possibilities of contributing values, advantages and disadvantages to learners, as well to the trend of science education in general are causing heated debates among scholars, educators and teachers. This is according to Jong, Linn, And Zacharia (2013) who state that "the value of physical laboratories for science based learning is generally recognized, but the value of virtual, simulated alternatives for hands-on physical laboratories is debatable" (p.305). Thus, by employing need analysis, this study is aimed at analysing strengths and weaknesses of virtual laboratories utilisation in science education. This paper aims o analyse the strengths and weaknesses of virtual laboratories and suggest the possible prospects of virtual laboratories usage in science education in Jambi Province Indonesia.

\section{RESEARCH METHEDOLOGY}

Qualitative research methods are particularly geared towards uncovering concepts and meanings assigned to people's experiences (Creswell, 1998). This study was conducted using the qualitative method, specifically documentary analysis. Research was conducted through internet findings and database as well as one on one personal communication with the relevant authority from the Ministry of Education in Jambi Province Indonesia. The most suitable and efficient data gathering required in order to dissect such project inside out is qualitative. The data gathered are then processed 
in accordance to the documentary analysis to determine the strength, weakness and prospects of virtual laboratory. From this, the relevance and implication of the project's application was better discovered and understood.

Documentary analysis is a form of qualitative research in which documents are interpreted by the researcher to give voice and meaning around an assessment topic. Analysing documents incorporates coding contents into themes which are similar to how focus group or interview transcripts are analysed. Three primary types of documents are as the following.

1. Public Records: The official, on-going records of an organization's activities. Examples involve syllabi, student transcripts, assignment reports, annual reports, and programme manuals, student handbooks, planned.

2. Personal Documents: First-person accounts of an individual's actions, experiences, and beliefs. Examples include schedules, journals, newspapers, event reports, blogs, Facebook, and e-mails.

3. Physical Evidence: Physical objects found within the study setting (often called artefacts). Examples include programs, material, brochures, posters, and handbooks.

(https://www.studentvoice.com/app/wiki/ retrieved on December, $20^{\text {th }} 2016$ )

In the course of this research project, the writer utilises library materials and field research. During the library research, the researcher collects and study materials, books and thesis which are related and relevant to this topic.

\section{RESULTS AND DISCUSSION}

\section{The strength of using virtual laboratory to enhance teaching science education}

Virtual lab is a computer program designed to simulate the real life laboratory works and experiments (Keller \& Keller, 2005). According to Kutluca, (2010) virtual lab is a tool to achieve a high quality learning by providing virtual apparatus, algorithm, and other equipment in particular discipline. Main component of virtual lab is: 1) laboratory setting and equipment; 2) computer set; 3) computer network; 4) virtual lab program; 5) partnership management and policy; and 6) engineering division.

According to experts, characteristics of virtual lab base education strength is basically explained as follows: a) creates novel knowledge, b) builds knowledge and internalizes information, c) motivates and guides the students, d) registers student information automatically and evaluates them, e) simulates experiments that are either dangerous and/or expensive, f) optimizes time consumption on learning process, g) improving student's academic achievements, h) improving student's conceptual understandings, i) specially suitable for children with visual learning style (Gunhaart \& Srisawasdi, 2012).

Virtual lab uses computer program to simulate series of experiments without physically doing them. It provides students with tools, material, and laboratory set 
virtually on the computer to carry experiments subjectively anytime and anywhere (Babateen, 2011). Virtual lab also enables students to simulate the laboratory works that are impossible to carry on real life. Virtual lab can help students to explore visualize abstract concepts in science application (Başer \& Durmuş, 2010). Some benefit of virtual lab are : (1) enable students to create alternative experiments because of the time and cost efficiency, (2) enable students to achieve understanding on macroscopic, submicroscopic, and symbolic level (3) provides dynamic representation of submicroscopic particle, (4) contributes to a better understanding on chemical compounds, (5) strongly motivates students (Herga, Grmek, \& Dinevski, 2014).

Virtual lab can also improve conceptual thinking and investigation performance (Chien, Tsai, Chen, Chang, And Chen, 2015). The study of (Nainggolan, 2014) in Jambi Indonesia generally highlighted that students consider the biology subject as a difficult subject and practical aspect is very boring, especially in the discussion of cell division is considered abstract in learning. Consequently slightly fewer students are not even interested in understanding and mastering the basic concepts in this biological material. As a result of the existing difficulties in implementing the biology, visual lab is expected in particular to the material of cell division is made more attractive. Therefore, teachers must have the ability to develop a media lab and take advantage of the media such as supporting medium so that the learning objectives can be achieved. Based on the results obtained from the research, media lab based Virtual Laboratory is eligible to be used as supporting media lab. It can be seen from the percentage of expert validation of media and subject matter experts, namely $98 \%$ and $80 \%$ with excellent product category and further tested on students (respondents) to determine the feasibility of the use of media by $80.5 \%$ with very good category. Based on the research results, it can be seen that the supporting media lab that has been developed can improve creativity among students, learning is also more fun and not feel bored, presentation of material in this medium is more easily understood and able to make the students learn independently. The researcher suggests the needs for the visual lab development in Jambi to produce instructional media better and more completely so that it can add interest and motivation of students.

Furthermore, the study of (Mahdini, 2014) aimed to determine the effect of use media Virtual Laboratory on the student results in the colligative properties of material in SMA 11 Tebo, Jambi. This type of research used the quasi-experimental and the results shows difference between the value of the initial test and final test students and the average values obtained experimental value is 52.33 and the average value the control class is 34,67 . It means that the average learning outcomes for experimental class and control class is different based on the results of research and discussion, it was concluded that there are significant media use virtual laboratory 
against results students in the material colligative properties in Government High School in 11 Tebo, Jambi.

In addition the result obtained from the study of (Ismail, Permanasari, \& Setiawan, 2016) that was conducted in Tanjung Jabung Barat, Propinsi Jambi, Indonesia shows that there are improvements in student's scientific attitude after treatment with STEM based virtual lab. The researchers explained that class $7 \mathrm{~b}$ (experimental class) showed higher improvement than class $7 d$ (control class). Highest gain of class both classes were scored on the third scientific attitude indicators at $49.09 \%$ for $7 \mathrm{~b}$ and $29 \%$ for class $7 \mathrm{~d}$. Considering the improvements of student's scientific literacy after the usage of STEM based virtual lab, we concluded that the product is very effective to be used in learning process. The use STEM based virtual lab on science learning is proven to be effective in enhancing student's scientific literacy, as shown by the test data. This result is in agreement with a research by (Adolphus, Telima, and Arokoyu, 2012) which states that ICT can help student in science learning by giving access to information, measuring, and analysis

\section{Shortcomings in the application of virtual lab}

Despite the overwhelming benefits, virtual lab has several disadvantages i. e: a) lack of physical interaction between hardware's, equipment, teacher, and students; $b$ ) the need of computer and specific tools; c) the need of technical expert staff, instructor, and curriculum expert to design and produce the lab; d) virtual lab cannot enhance social and psychomotor skill as good as real lab should (Tiwari, Nafees, \& Krishnan, 2014). In addition, as Virtual labs to some extent cannot fully fulfil the whole needs of real labs, they may still be supplemental aids for science labs. It is because, although the visualisation provided in Virtual labs through animations, several concepts of sciences are only demonstrated partially which and depends on how well the software is developed. For example, a study by Salam, Setiawan, and Hamidah (2010) shows that four out of seven physics theoretical concepts are confidently mastered by students in experimental group using virtual labs for physics practicum class. Besides that, according to them with reference to Edgar Cole's cone of experience, practicum experience using Virtual labs is considered at simulating or modelling the real experience level. Therefore, still using virtual labs for science practicum might not fully fulfil the real experience of practicum for students.

In addition, "[t]he most mentioned drawback of the VLs by the students is that they cannot feel, smell or touch" (Tatli \& Ayas, 2010, p. 941). From this notion, it is clear that virtual labs might not totally provide whole learning experiences as the students who are engaged with the virtual labs cannot get sensual experiences from the virtual labs. Although the "...latest innovations named "haptic" that technology bring in education enables user to feel touch sensation" (Tatli \& Ayas, 2010, p. 941), the other sensations like smell and heat are not sensed by the students. To some extents, these sensory experiences are important especially in chemistry practicum 
class, as for instance, where students should experience heat and smell from a beaker containing certain solution. As another example, students also will lose their opportunity of "...feeling the resistance of large masses to efforts to move them promotes an understanding of mass and inertia. Tasting baking soda and vinegar can help to develop an understanding of acids and bases" (Keller \& Keller, 2005, p. 10).

Apart from that, engaging with virtual labs makes students less active. Since virtual lab is a kind of digital computerised tools, it does not require the users to actively interact with it. Mostly, it asks only clicking the mouse or pressing the keyboard. Meanwhile, real lab practicum activity demands students to make more certain physical movements, such as careful pouring in chemistry practicum class or speed rubbing and gentle pulling in physics practicum activities, and so on. In short, the students who use virtual labs for practicum activities may lose some important learning experiences.

\section{Prospect of virtual laboratory}

The prospects of virtual labs are possibly anchored on the virtual labs' definitions and concepts. The prospects of their usages might also be generated, in general, from the benefits of their usages. This part initially present the definitions and concepts of virtual labs and their benefits, then provide some fields where the virtual labs may offer their prospective usages. The following are several aspects of prospective usages of virtual labs.

\section{Financial Resources and Academic Benefits}

Firstly, financial and academic aspect may take the benefit from the virtual labs usages. It can be seen from the below quotation that defines virtual labs as:

\section{...laboratory experiments without real laboratory with its walls and doors.}

It enables the learner to link between the theoretical aspect and the practical one, without papers and pens. It is electronically programmed in computer in order to simulate the real experiments aims inside the real laboratories. (Harry \& Edward, 2005 in Babateen, 2011, p. 101)

The definition of virtual labs above implies the financial resources prospective whereby the needs of four-by-four building or cube shaped room for school laboratories are no matter anymore. They are substituted by sets of computer. Besides that, experimental tools and sets are substituted by the items and features provided in the software. In addition, the academic aspects also may have the prospective usages of virtual labs. Compared to traditional labs, based on the definition above, virtual labs help students linking theories learned to the practical simulations. Simultaneously, this gives a beneficial contribution to academic development where students' theoretical mastery is assisted by virtual labs usages in practicum class. 


\section{Time Effectiveness}

Time effectiveness aspect is also an aspect that virtual labs usage provides their prospects to. It can be seen from the following quotation that describes a virtual lab as a virtual studying and learning environment that aims at developing the lab skills of students. This environment is located on one of the internet pages. Usually, this page has main page and many links, which are related to laboratory activities and its achievements (Zaitoun, 2005 in Babateen, 2011).

Since the above quotation mentions the availability of virtual labs on the internet, on-line laboratories will abbreviate the practicum activities whenever and wherever the students need as long as they have internet connection on their computer. At this point, students do not need to wait four their turn in school to do science practicum activities. Once they have learned the theories from the classroom, they can explore to link theories to practical knowledge and laboratories skills by themselves at any time on the internet. Apparently, virtual labs are considered prospective to be used to avoid time-consuming practicum activities, especially online virtual labs.

\section{Computer Simulation Technology Advancement in Education}

Since virtual labs are designed to model the real world, most virtual labs employ simulations based on algorithm to deploy the result of complex calculations attained from the real world. This is a prospective development for the computer simulation technology as it will also advance the use of technology in educational field. This notion is in line with Keller and Keller (2005) who maintain that:

For several years now, software vendors have provided computer-based virtual labs. These almost always show simulations of experiments based on computer algorithms, which are often simple equations. Typically, the student selects which simulation to watch, much like picking a scene to watch on a DVD. The scene may be animated, and would most likely include a graph and data table. Like the paper-andpencil lab, the data are predefined, this time by the algorithm on which the simulation is based. The student watches the scene and might draw conclusions about the simulation, but does not engage in scientific process. This variety of virtual lab is more accurately described a virtual demonstration (demo) or simulated lab. (p. 5)

Clearly, by using virtual labs, although students do not engage with the scientific process, they still can obtain practical gain of certain theories and concept through animated or video-taped data simulation in virtual labs. Furthermore, the students may also get assisted to draw a conclusion from the simulation provided in virtual labs as the way they conclude in physical laboratories. In addition, the more virtual labs software is developed to meet the needs of educational fields, the more sophisticated simulation advancement will be. Therefore, it can be said that another 
prospect of virtual labs is in the computer simulation technological advancement in educational fields.

\section{Cultural Aspects}

A computer is not just electronic goods, but also a symbol of modernisation. Introducing a computer based virtual laboratories at schools is culturally always challenging. At some points, computer or digital tools and devices are found used by citizen more attractive. In the context of educational settings, virtual labs as an infusion of digital products into educational system contribute both positive and negative impacts to the cultural life of schools' environment. Jambi as a developing province in Indonesia is experiencing a cultural transition from traditional to modern lifestyle, from agriculture to an industrial society. Virtual labs usage in a few school had been introduced for senior high schools students and had been evaluated their effects on students' studies improvement (Ismail et al., 2016; Lerianti, Hasibuan, \& Afrida, 2014; Mahdini, 2014; Rahayu, Fuldiaratman, \& Ernawati, 2014). However, there is no specific discussion on their studies that directly links between the use of virtual labs and the cultural aspects of learning. Hence, the cultural prospects of virtual labs in this part are yielded from the normative inferences.

Since, digital devices such as mobile phones, personal computers, and laptops are more and more owned by many students in Jambi, social and cultural relationship among them experienced quite massive changes. This affects their awareness and capability of using digital tools in daily life, including in the ways of their learning at school. The studies mentioned above show positives findings on virtual labs usage in science classes. This could more or less be influenced by the cultural slides forward experienced by the students towards digital or virtual world. Moreover, the feedback from virtual labs usages itself may bring also positive impact to students culture in using digital tools such as gadgets and laptops for learning purposes once they ever introduced to virtual labs at schools. At this stage, cultural prospect of virtual labs usages bring mutual advantages either from the usage of virtual labs towards students' culture in using digital tools or vice versa.

\section{CONCLUSIONS}

We live today in the world of information society and the rate at which the technological change is happening is quite breath-taking. Especially in online medium, new learning technologies are introduced at such a fast rate that higher education faculty feel compelled to learn and adapt to the new technological innovations (Oh \& Reeves, 2014). Literature studies in higher education have explored the ways virtual labs can be leveraged for enhanced learning that allow students to be intellectually challenged in their learning process. Furthermore, research has indicated interactive learning outcomes through virtual labs foster student 
engagement (Merchant, Goetz, Cifuentes, Keeney-Kennicutt, \& Davis, 2014) and assist faculty in evaluating students' performance (Rodriguez, Soria, \& Campo, 2015). As expectations increase for undergraduate technology faculty to incorporate studentcentered learning activities, there will be greater use of innovative technologies to help them achieve this goal. There are concerns regarding attitudes, institutional support, and technical assistance in regards to the infusion of virtual labs in the undergraduate IT program. If these faculty concerns are not addressed, educators may not embrace, learn, and implement this educational innovation to continue adopting the virtual labs in their IT classrooms every following semester (Drape et al., 2013).

\section{REFERENCES}

Adolphus, Telima, \& Arokoyu, A. A. (2012). Improving Scientific Literacy among Secondary School Students through Integration of Information and Communication Technology. ARPN Journal of Science and Technology, 2(5), 444448.

Amorim, T., Tapparo, L., Maranghello, N., Silva, A. C., \& Pereira, A. S. (2014). A Multiple Intelligences Theory-based 3D Virtual Lab Environment for Digital Systems Teaching. Procedia Computer Science, 29(1), 1413-1422.

Babateen, H. M. (2011). The role of Virtual Laboratories in Science Education, 12, 100104.

Başer, M., \& Durmuş, S. (2010). The Effectiveness of Computer Supported Versus Real Laboratory Inquiry Learning Environments on the Understanding of Direct Current Electricity among Pre-Service Elementary School Teachers. Eurasia Journal of Mathematics, Science E Technology Education, 6(1), 47-61.

Chien, K.-P., Tsai, C.-Y., Chen, H.-L., Chang, W.-H., \& Chen, S. (2015). Learning Differences and Eye Fixation Patterns in Virtual and Physical Science Laboratories. Comput. Educ., 82(C), 191-201. https://doi.org/10.1016/j.compedu.2014.11.023

Common Labs Accident. (2016).

Creswell, J. W. (1998). Qualitative Inquiry and Research Design: Choosing mong Five Traditions. Thousand Oaks, CA: Sage Publications.

De Jong, T., Linn, M. C., \& Zacharia, Z. C. (2013, April). Science Magazine, 340(April), 305-308.

Gunhaart, A., \& Srisawasdi, N. (2012). Effect of Integrated Computer-based Laboratory Environment on Student Physics Conceptual Learning of Sound Waves Properties. Procedia Social and Behavioural Sciences, 46, 5750-5755. https://doi.org/10.1016/j.sbspro.2012.06.510

Herga, N. R., Grmek, M. I., \& Dinevski, D. (2014). Virtual Laboratory as an Element of Visualization when Teaching Chemical Contents in Science Class. The Turkish Online Journal of Educational Technology, 13(4), 157-165. 
Ismail, I., Permanasari, A., \& Setiawan, W. (2016). Stem Virtual Lab: An Alternative Practical Media to Enhance Student's Scientific Literacy. Jurnal Pendidikan IPA Indonesia, 5(2), 239-246.

Jagannathan, U. (2016). Higher Education Faculty Perceptions of the Infusion of Virtual Labs in IT Degree Programs: An Exploratory Multi-Case Study. Northcentral University.

Johnson, L., Adams Becker, S., Estrada, V., \& Freeman, A. (2015). NMC Horizon Report: 2015 Higher Education Edition. Austin, Texas.

Karadeniz. (2013). Effect of a Virtual Chemistry Laboratory on Students ' Achievement. Technical Education, 16, 159-170.

Keller, H. E., \& Keller, E. E. (2005). Making Real Virtual Labs. The Science Education Review, 4(1), 2-11.

Kutluca, T. (2010). Investigation of Teachers' Computer Usage Profiles and Attitudes toward Computers. International Online Journal of Education Sciences, 2(1), 81-97.

Lerianti, E., Hasibuan, M. H. E., \& Afrida. (2014). Perbandingan Hasil Belajar Dengan Menggunakan Laboratorium Nyata dan Laboratorium Virtual dalam Materi Asam Basa Kelas XI IPA SMA Nusantara Kota Jambi. Jambi.

Mahdini, S. (2014). Pengembangan Media Pembelajaran Laboratorium Virtual Pada Materi Uji Zat Makanan Untuk Siswa Kelas XI SMA. Universitas Jambi.

Merchant, Z., Goetz, E. T., Cifuentes, L., Keeney-Kennicutt, W., \& Davis, T. J. (2014). Effectiveness of Virtual Reality-based Instruction on Students' Learning Outcomes in K-12 and Higher Education: A Meta-nalysis. Computers $\mathcal{E}$ Education, 70, 29-40. https://doi.org/https://doi.org/10.1016/j.compedu.2013.07.033

Nainggolan, L. (2014). Pengembangan Media Praktikum Berbasis Laboratorium Virtual (Virtual Laboratory) pada Materi Pembelahan Sel di SMA. Jurnal Penenilitian Universitas Jambi, 1-7.

Oh, E., \& Reeves, T. C. (2014). Generational Differences and the Integration of Technology in Learning, Instruction, and Performance. In J. M. Spector, M. D. Merrill, J. Elen, \& M. J. Bishop (Eds.), Handbook of Research on Educational Communications and Technology (pp. 819-828). New York, NY: Springer New York. https://doi.org/10.1007/978-1-4614-3185-5_66

Rahayu, S. U., Fuldiaratman, \& Ernawati, M. D. W. (2014). Pengaruh Media Laboratorium Virtual dalam Pembelajaran Larutan Penyangga Terhadap Hasil Belajar Siswa Kelas XI IPA SMAN 8 Muaro Jambi. Jambi.

Rodriguez, G., Soria, Á., \& Campo, M. (2015). Virtual Scrum: A teaching aid to introduce undergraduate software engineering students to scrum. Computer Applications in Engineering Education, 23(1), 147-156. https://doi.org/10.1002/cae.21588

Salam, H., Setiawan, A., \& Hamidah, I. (2010). Pembelajaran Berbasis Virtual Laboratory untuk Meningkatkan Penguasaan Konsep pada Materi Listrik Dinamis, (November), 8-10.

Tatli, Z., \& Ayas, A. (2010). Virtual Laboratory Applications in Chemistry Education. 
Procedia - Social and Behavioral Sciences, 9, 938-942. https://doi.org/http://dx.doi.org/10.1016/j.sbspro.2010.12.263

Tiwari, S. R., Nafees, L., \& Krishnan, O. (2014). Simulation as a pedagogical tool: Measurement of impact on perceived effective learning. The International Journal of Management Education, 260-270. https://doi.org/https://doi.org/10.1016/j.ijme.2014.06.006 